\title{
Rules of Engagement: Considering Good Policy and Practice with Online Military Learners
}

\author{
David Starr-Glass \\ University of New York Prague \\ Prague, Czech Republic
}

\begin{abstract}
In online distance learning environments military learners may not stand out or be particularly distinctive from their non-military peers. However, military learners do possess a degree of difference that needs to be recognized. The military can be considered to possess a Janusian culture-two distinctive cultural patterns that emerge in different situations. The culture military learners display in online distance learning situations is not particularly different from their non-military peers. However, online facilitators should be aware of the cultural dimension and the difficulties military learners encounter when participating online. Drawn from the author's ten years' experience working with military learners, this article explains these different cultural perspectives, explores the negative impacts of stereotyping, and provides practical suggestions for harnessing the strengths of these learners in productive online learning.
\end{abstract}

\section{Introduction}

One of the first things that the online distance learning facilitator encounters when working with military learners is $V / R$-it always comes at the end of emails, and often at the conclusion of online postings. It stands for Very Respectfully and is part of the culture and etiquette of military correspondence. It is the contention of this article that V/R should be understood literally-not simply as a pleasantryand viewed as something that should characterize the relationship between online instructors and their military students. Service members who participate in online distance learning environments are entitled to the respect of their instructors and the institutions in which they are enrolled. They are entitled to be understood as learners with distinct concerns and unique narratives, and they are also entitled to be supported in acquiring the knowledge and academic success that they desire.

This is not a plea, however, for special treatment towards military learners: all learners in higher education are entitled to recognition and respect. The respectful recognition of the uniqueness of the individual is the starting point from which the process of effective learning begins. Respectful recognition is also the pre-requisite for educational engagement that promises "maximal opportunities for intellectual 
and creative development... [or the] careful and comprehensive preparation for whatever may lie beyond graduation, whether it be graduate school, professional school, or first professional position” (Boyer Commission, 1998, p. 12).

This is the right of all learners. However, in order to maximize the opportunities for the intellectual development of military learners it is necessary to recognize their unique characteristics. All too often, military members can become victims of stereotyping - this happens in higher education and also in the workplace (Hairston, 2010; Harrell \& Berglass, 2012). The distinctive needs and requirements of military learners are unrecognized (often innocently), or used against them. Even military learners' access to special government-backed tuition assistance has made them targets of aggressive and predatory educational marketing (Harkin, 2010; Swail, Redd, \& Perna, 2003; United States Senate, 2012).

Military students are representatives of a minority culture and "like members of other minority cultures, student service members and veterans encounter misunderstanding and stereotypes about their motives and experiences” (Sternberg, MacDermid, Vaughan, \& Carlson, 2009, p. 7). These encounters are increasing in occurrence because the number of military learners on American campuses and in online distance learning programs has risen dramatically-whether as veterans, active service members, or dependents of military families (Radford \& Weko, 2011). In part, the increased presence of the military is a consequence of more generous tuition assistance programs which benefited active service members after September 10, 2001 (Supplemental Appropriations Act, 2008). But other factors have also contributed to this increase: the downsizing of the U.S. military, the continuing weakness of the domestic economy, low job creation and increased competitiveness in the labor markets, and the need for those in the military to secure higher education qualifications before they separate from service (Radford, 2009; Steele, Salcedo, \& Coley, 2010).

When they enter higher education, military learners are often confronted by a process that is offputting, culturally alienating, and bureaucratically convoluted (Griffin \& Gilbert, 2012). Some institutions of higher education have responded positivity to these challenges by providing services that are more appropriately geared to incoming military, by educating faculty members and administrators who deal with them and by making the college campus a more military friendly environment - but, despite all of this, the military learner is too often short-changed and left unsupported (Ackerman \& DiRamio, 2009; DiRamio \& Jarvis, 2011; McBain, Kim, Cook, \& Snead, 2012).

This article considers active military members who participate in online distance learning environments. It examines the role of the instructor/facilitator of these learning experiences and suggests ways in which appropriate policy and practice can be developed that serve the needs of military learners. It is exploratory and not prescriptive. The observations and suggestions made are based on the author's ten years of facilitating and researching online distance learning environments with an American university that has a long and successful history of working with the military (Starr-Glass, 2011a, 2013, 2014a). The first section considers the culture of the military and the extent to which this impacts learning environments, or is likely to precipitate stereotypical responses on the part of others. The second section examines the opportunities, challenges, and considerations that military learners bring with them to the learning environment. The final section suggests areas for effective practice, increased learning and satisfaction, and improved retention rates in online distance learning.

\section{Different but Not Too Different: Two Faces of the Military Student}

The military represent one of the oldest organizations in existence. Like all organizations it has developed its own culture-constellations of assumptions, norms, values, rituals, and social behavior. In his classic analysis of the military Lang (1965) drew attention to its organizational structure and cultural expression: communal living; control over all aspects of the members' lives; rigid hierarchical command structures; and the downward flows of authority, communication and directives. Organizational cultures are important because they provide a blueprint for participant behavior, help socialize new members and 
provide internal continuity and cohesion. Military cultures are characteristically described as strong, but even strong cultures change when confronted with significant shifts in the external context within which they exist (Dorn, Graves, Ulmer, Collins, \& Jacobs, 2000; English, 2004).

After an extensive comparative study of military organizations, Soeters and his associates (Soeters \& Recht, 1998; Soeters, Winslow, \& Weibull, 2006) concluded that their cultures consisted of two components. All possessed a distinctive supra-national culture, but they also displayed a set of values similar to the cultures of domestic non-military organizations. These two cultural components were inevitably shaped by the broad national cultures within which they were embedded (Hofstede, 1980, 1986). Soeters et al. (2006) suggested that military service members were familiar with both cultural components and could switch from one to the other. In hot situations (conflicts and hostilities) military members automatically espoused the military culture; whereas, in cold situations (barracks and training exercises) they demonstrated cultural positions similar to non-military ones. In order to function effectively and to fulfill their complex roles in society, military organizations need to be able to embrace both cultural perspectives. This ability of the military and of military members to (metaphorically) look in two different directions at the same time was referred to by Soeters et al. (2006) as Janusian Culturefrom the two-faced deity of Roman mythology.

Understanding Janusian culture is important for those facilitating online distance learning environments. In their initial engagement with military learners, facilitators will find that these learners are similar to non-military students. Indeed, because these military learners are in a cold situation, the facilitator might believe that military and non-military learners are essentially the same; however, this is not the case. Online distance learning performance will be affected by a cluster of issues that are associated, albeit indirectly, with military culture and with the ever-present hot situation. Military learners have to navigate a life between their studies and their duties-duties which are often unexpected and difficult. It is not surprising that many military learners, even in the online environment, will exhibit "psychological issues of secrecy, stoicism and denial [that] add a layer of difficulty and possibly confusion [for the non-military facilitator]... who may see the world from a place of openness, fairness, and egalitarianism” (Hall, 2011, p. 16).

There is also another double-sidedness associated with military learners: the difference between instructors' assumptions of who they might be and who they actually are. Both of these aspects are important, especially for those who confront the military learner for the first time in their online course. Who we assume military learners are takes us into a landscape of stereotypes and self-fulfilling prophecies, sometimes naïve and sometimes sophisticated (Osland \& Bird, 2000). Who they actually are takes us into a more expansive landscape of andragogy and autonomous learning.

\section{Stereotyping and Self-Fulfilling Prophecies}

We find it unpleasant if accused of harboring stereotypes, but we never encounter the other without our framework of expectations, anticipated outcomes and pre-established assumptions. Stereotypes are "cognitive structures that incorporate a variety of features about social groups, including physical characteristics, attitudes, behavioral tendencies and affect associations" (Gadon \& Johnson, 2009, p. 637). The attribution of stereotypes is spontaneous rather than conscious-intuitive stereotype attribution provides a way of simplifying decision making, limiting informational overload and preserving cognitive resources (De Neys \& Vanderputte, 2011; Macrae, Milne, \& Bodenhausen, 1994). The mechanism of stereotyping is imprecisely understood; indeed, after an extensive review Hilton and von Hippel (1996) remarked that "to the extent that there is a single message to be gleaned from the current review, it is that there is indeed no single message: Stereotypic thinking is clearly multiply mediated" (p. 262). 
Although there is a lack of clarity about their origins, stereotypes are pervasive, often innocently ascribed, remarkably persistent, usually unchallenged, resistant to revision and place significant limits on our ability to understand others in considered and nuanced ways (Epley \& Gilovich, 2006). In many cultures, especially the United States, the military and its members can be negatively stereotyped: e.g., the military may be seen as a job of last resort, a warrior culture centered on aggression and violence, or a group distanced and alienated from the normative values of society. Particularly in the wake of American involvement in Vietnam, these stereotypes have hardened and there has been what many regard as a particularly unhealthy alienation between the university and the military (Downs \& Murtazashvili, 2012).

Complicating and compounding military stereotypes are ethnic and gender stereotyping. Although statistically the U.S. military is diverse and representative of the general population, there is a strong tendency for lower pay-grades (non-officers) to have a disproportionately higher representation of women and ethnic minorities (Armor \& Gilroy, 2010; DoD, 2012). This is important because the online instructor will normally encounter military learners with lower pay-grades in their courses (officers usually received their commissions after earning college degrees).

Stereotypes are important because they can easily lead to self-fulfilling prophecies. These occur when pre-conceived expectations held about individuals are communicated to them and lead them to perform in ways that actually confirms the initial expectation, even though it might have been objectively unwarranted. This exemplifies the strength, power and consequential impact of initial stereotyping for both parties. Depending on the nature of the initial labeling, self-fulfilling prophecies can be positive and lead to demonstrably superior outcomes (the Pygmalion Effect), or they can be negative and result in actual underperformance (the Golem Effect) (Chang, 2011; Riley \& Ungerleider, 2012).

\section{Andragogy and Autonomous Learners}

Pedagogy, which literally means "leading children to instruction," has been traditionally used to describe the tactics and strategies that instructors employ in the teaching process. The word, however, is replete with assumptions of power differentials, attributions of authority and the directionality of the instructional process.

When Knowles (1970) started to use the term andragogy to describe the instruction of adults, he was drawing on and making explicit a body of research and practice that had a long history, at least in Europe (Taylor \& Kroth, 2009). Andragogy approaches the learning process by recognizing that adult learners have a number of distinctive attributes: they are self-directed, possess considerable life experience, are ready to learn, seek relevance in their learning and are self-motivated in their learning efforts (Knowles, 1984; Merriam \& Caffarella, 1991).

Recognition of military learners begins with the acknowledgement that they are adults; respect is displayed by treating them as adult learners. A significant point to consider is that, compared with nonmilitary students of the same age, military learners usually have extensive work experience and have been placed in positions of considerable responsibility. Compared with their non-military peers, military learners have usually travelled extensively and have acquired understandings of different cultures (although they might not necessarily have reflected on these experiences). All of these factors represent considerable assets in most online distance learning environments and provide rich experiential territory to explore (Starr-Glass, 2011a).

Military learners are generally motivated and intuitively engaged in autonomous learningindeed, such behavior tends to characterize them. Autonomous learning has been defined as "the characteristic of the person who independently exhibits agency (i.e., intentional actions) in learning activities” (Ponton \& Carr, 2000, p. 273). Autonomy in learning and self-directionality in learning situations are characteristic of adult learners, although "it is the personal characteristics of the learner- 
including his or her qualities of mind and behavior (personality) as well as acquired skills and abilitieswhich ultimately determine whether self-directed learning will take place in a given learning situation” (Guglielmino, Long, \& Hiemstra, 2004, p. 1).

Military learners, whether they remain with the military or separate from it, have found that autonomous learning is of critical importance in their professional lives-it is part of their culture (Mensch \& Rahschulte, 2008). It has been argued that autonomous learning can be further promoted by allowing learners to focus on their learning activities through self-monitoring, and by reinforcing their self-perception as continuous learners (Ponton, Derrick, \& Carr, 2005). Military learners bring with them a propensity for autonomous learning, but online instructors can make this salient by encouraging learners to use their previous military experiences in their current coursework, by providing the opportunity to share it with others, and by supporting their efforts to reflect on it.

\section{Rules of Engagement: Things to Consider}

Because of its accessibility, the online distance learning environment is usually a place where learners of different cultural and ethnic heritages come together. This requires the facilitator to recognize diversity and to promote inclusion. It can be challenging to accommodate and respond to the differences of learners from a wide range of cultures, however sometimes the online environment will be populated by a specific group and then there is an educational advantage in trying to learn more about that particular group (Starr-Glass, 2014b). Often, military learners will form a significant number of participants, perhaps the majority, and this provides the facilitator with the opportunity to learn more about them and to create an environment that accepts and accommodates their specific characteristics.

- Develop a general awareness of military learners. Remember that military students may be veterans, active service members, or the dependents of military families. While these are separate groups, they are defined by their military culture. The military becomes family for its members and for their families. Park (2011) reminds us that "a common saying in the military is that when one person joins, the whole family serves ... military families may often be in the background of public discourse on the military, but they are critical to its success" (p. 65). A strong sense of group loyalty and attachment pervades what is essentially an extended family, because "the military recruits individuals but retains families ... family members are important stakeholders affected by military policies and culture” (Kelty, Kleykamp, \& Segal, 2010, p. 192). Although not generally considered to be military members, the dependents of the military in online distance learning contexts display many of the features of the military. As Kudler and Porter (2013) note “military children don't wear uniforms, and they may be hard to recognize in their communities... yet they serve and sacrifice alongside their parents in ways that often go unappreciated" (p. 168). Developing knowledge and awareness about the military will come through online distance learning exchanges, but it is better for the facilitator to be prepared and sensitized to the issues that might arise beforehand (Coleman, 2006; Hall, 2008; Martin, 2012).

- Cultivate an empathetic appreciation of individual learners. Online facilitators should try to create online environments that are conducive to effective learning. Doing that requires an appreciation of participants. The unique lives and contexts of military learners should be appreciated in ways that lead to an empathetic understanding, rather than to judgmental interventions. Empathetic connections acknowledge respectful distance, meaningful exchange, and an appreciation of the learner's unique selfhood. Military learners, just as their non-military peers, are best recognized as unique individuals. While they neither need special favors nor demand differential treatment, they are entitled to be understood as individuals not 
as representatives of a particular class. Information about the learner is particularly useful in designing and facilitating online distance learning environments. It can be advantageous to request, on a voluntary basis, information that the learner thinks may be relevant. The present author requests learners to submit a course participant survey at the outset of an online course, allowing them to raise concerns and considerations that they believe might be significant. The survey not only provides valuable information, but also creates a communication bridge between the learner and instructor (Starr-Glass, 2011b).

- Maintain a prominent social and instructional presence. A persistent complaint of military learners, but not one restricted exclusively to them, is the lack of a strong instructional and social presence online. In online courses transactional distance, limited social dynamics, and the short duration of the learning experience all require the facilitator to be active socially and cognitively. Military learners tend to be highly motivated and involved in their learning experience and demand the same of their instructors. They have strong expectations of involvement and inclusion in a community of learning; indeed, they are particularly sensitive to a developing sense of community in online courses. The lead role of the instructor is to establish a rich and supportive environment in which exchange, sharing, and dialogue are actively promoted. It might seem self-evident, but it needs to be kept in mind that "in this age of dazzling technology, there is still no substitute for interaction...opportunities for students to interact in multiple ways with their peers" (Shackelford \& Maxwell, 2012, p. 241). As a result of their service, training, and commitment military learners tend to favor online environments that are active and that have a strong community ethos. Creating such communities begins with the direction, presence and involvement of the instructor.

- Utilize the richness of military learner prior experience. Military learners are likely to possess a rich experiential history, with exposure to organizational culture, leadership, decision-making, different management styles, other managerial involvement and organizational engagement. Depending on age and rank, they may possess considerable supervisory and management experience and may have been responsible for significant budgets. Military learners might have had long-term stays in foreign countries, developed some appreciation of different national cultures or learned a foreign language. This richness of experience and experiential learning is often in stark contrast with non-military students and it can often be used constructively, depending on the subject matter that is being explored. Utilizing prior experience allows the learner the opportunity for critical reflection on their previous engagements and outcomes. Sharing experience allows others to gain new perspectives vicariously. It also provides a context within which present knowledge can be recognized as relevant—connected and explaining the past.

- Ensure scheduling and participation flexibility. A significant feature of the military learner's life is unannounced change: e.g., unanticipated increases in workload, sudden deployment and relocation, and TDY (temporary duty). Students appreciate that change is a fact of service life, that there is usually no opportunity to defer or change the assignment and that "the mission always comes first." They are also usually very concerned about the impact of change on their ability to participate in online distance learning courses, appreciating that although they "permit more flexibility than traditional place-bound courses, absenting oneself from an online learning experience can take its toll on learners" (Conrad, 2009, p. 14). For the military learner training exercises, deployment, or TDY can also be associated with the inability to access the Internet. There is little doubt that regular and consistent participation in online courses leads to optimal learning results. However, in working with military learners the instructor needs to be flexible and present opportunities that allow learners to overcome 
participation difficulties. Likewise, in designing the learning environment consideration has to be given to learners who are in locations where Internet reliability and bandwidth are limited.

- Ensure diversity, inclusion and equity. In creating and facilitating the online learning environment the instructor needs to consider the military learner and the challenges that they encounter. However, the solutions provided should be available for all participants, including the non-military. When the learning environment contains both military and non-military learners, the goal should be to recognize that the synergistic advantages presented by student diversity can only be utilized if all students are included. The overriding consideration is not to provide special benefits or considerations for one designated group, but to ensure that all participants are treated in an equitable manner.

These suggestions constitute the basis of the rules of engagement for this present author when working with military learners in online distance learning contexts. They may also be useful to those who are about to work with military learners for the first time. Two features are evident. First, these suggestions do not vary significantly from those that might be used by instructors approaching any online learning situation with any group of students. This reflects the reality that the differences between military and non-military learners are not striking. The military learner confronts the same challenges that all online learners confront.

Second, while differences between the military and non-military learner are not great, they do exist. These differences lie in both the cultural experiences of military learners and the operational context within which they are involved. These factors shape the way in which military learners approach learning and subsequently mediate their performance in distance learning courses.

These suggestions for working with military learners stress that all learners are entitled to be recognized and respected, irrespective of their backgrounds and affiliations. Some might argue that military learners deserve more respect because of their service, but this is problematic if it translates into preferential treatment in the online learning environment-treatment that military learners themselves neither claim nor appreciate. Respect comes from appreciating the uniqueness of the learner as a learner, not as something else. In order to fully understand the learner as a learner it is inevitable that the instructor will also have to consider the context that has shaped the individual.

\section{References}

Ackerman, R., \& DiRamio, D. (2009). Creating a veteran-friendly campus: strategies for transition and success: New Directions for Student Services, No. 126. San Francisco, CA: Wiley/ Jossey-Bass.

Armor, D. J., \& Gilroy, C. L. (2010). Changing minority representation in the U.S military. Armed Forces \& Society, 36(2), 223-246.

Boyer Commission on Educating Undergraduates in the Research University. (1998). Reinventing undergraduate education: A blueprint for America's research universities. New York, NY: State University of New York Stony Brook.

Chang, J. (2011). A case study of the 'Pygmalion Effect': Teacher expectations and student achievement. International Education Studies, 4(1), 198-201.

Coleman, P. (2006). Flashback: Posttraumatic stress disorder, suicide, and the lessons of war. Boston, MA: Beacon Press 
Conrad, D. (2009). Cognitive, instructional, and social presence as factors in learners' negotiation of planned absences from online study. International Review of Research in Open and Distance Learning, 10(3). Retrieved from http://www.irrodl.org/index.php/irrodl/article/view/630/1296

De Neys, W., \& Vanderputte, K. (2011). When less is not always more: Stereotype knowledge and reasoning development. Psychology, 47(2), 432-441.

DiRamio, D., \& Jarvis, K. (2011). Veterans in higher education: When Johnny and Jane come marching to campus. ASHE Higher Education Report, 37(3), 1-144.

DoD (Department of Defense). (2012). 2012 Demographics: Profile of the military community. Office of the Deputy Assistant Secretary of Defense (Military Community and Family Policy). Retrieved from http://www.militaryonesource.mil/12038/MOS/Reports/2012_Demographics_Report.pdf

Dorn, E., Graves, H. D., Ulmer Jr., W. F., Collins, J. J., \& Jacobs, T. O. (2000). American military culture in the twenty-first century. Washington, DC: Center for Strategic and International Studies. Retrieved from http://csis.org/publication/american-military-culture-twenty-first-century

Downs, A. D., \& Murtazashvili, I. (2012). Arms and the university: Military presence and the civic education of non-military. Cambridge, UK: Cambridge University Press.

English, A. D. (2004). Understanding military culture: A Canadian perspective. Montreal, Canada: McGill-Queen’s University Press.

Epley, N., \& Gilovich, T. (2006). The anchoring-and-adjustment heuristic: Why the adjustments are insufficient. Psychological Science, 17(4), 311-318.

Gadon, O., \& Johnson, C. (2009). The effect of a derogatory professional label: Evaluations of a 'shrink.' Journal of Applied Social Psychology, 39(3), 634-655.

Griffin, K., \& Gilbert, C. (2012). Easing the transition from combat to classroom: Preserving America's investment in higher education for military veterans through institutional assessment. Washington, DC: Center for American Progress. Retrieved from http://cdn.americanprogress.org/wp-content/uploads/issues/2012/04/pdf/student veterans.pdf

Guglielmino, L. M., Long, H. B., \& Hiemstra, R. (2004). Self-direction in learning in the United States. International Journal of Self-Directed Learning, 1(1), 1-17.

Hairston, K. R. (2010). A composite counter storytelling: Memoirs of African American military students in Hawaii public schools. The Qualitative Report, 15(4), 783-801. Retrieved from http://www.nova.edu/ssss/QR/QR15-4/hairston.pdf

Hall, L. K. (2008). Counselling military families: What mental health professionals need to know. London, UK: Routledge.

Hall, L. K. (2011). The importance of understanding military culture. Social Work in Health Care, 50(1), 4-18.

Harkin, T. (2010). Benefitting whom? For-Profit education companies and the growth of military educational benefits. Washington, DC: United States Senate - Health, Education, Labor, and Pensions Committee. Retrieved from http://www.harkin.senate.gov/documents/pdf/4d0bbba63cba1.pdf

Harrell, M. C., \& Berglass, N. (2012). Employing America's veterans: Perspectives from businesses. Washington, DC: Center for a New American Security. Retrieved from http://www.cnas.org/files/documents/publications/CNAS_EmployingAmericasVeterans_HarrellB erglass.pdf

Hilton, J. L., \& von Hippel, W. (1996). Stereotypes. Annual Review of Psychology, 47, 237-271. 
Hofstede, G. (1980). Culture's consequence: International differences in work-related values. Newbury Park, CA: Sage.

Hofstede, G. (1986). Cultural differences in teaching and learning. International Journal of Intercultural Relations, 10(3), 301-320.

Kelty, R., Kleykamp, M., \& Segal, D. R. (2010). The military and the transition to adulthood. The Future of Children, 20(1), 181-207.

Knowles, M. S. (1970). The modern practice of adult education: Andragogy versus pedagogy. New York, NY: Association Press.

Knowles, M. S. (1984). Andragogy in action. San Francisco, CA: Jossey-Bass.

Kudler, H., \& Porter, R. I. (2013). Building communities of care for military children and families. Future of Children, 23(2), 163-185.

Lang, K. (1965). Military organizations. In J. G. March (Ed.), Handbook of organizations, (pp. 838-878). Chicago, IL: Rand McNally.

Macrae, C. N., Milne, A. B., \& Bodenhausen, G. V. (1994). Stereotypes as energy-saving devices: A peek inside the cognitive toolbox. Journal of Personality and Social Psychology, 66(1), 37-47

Martin, T. L. (2012). Combat in the classroom. Writing on the Edge, 22(2), 27-35.

McBain, L., Kim, Y. M., Cook, B. J., \& Snead, K. M. (2012). From soldier to student II: Assessing campus programs for veterans and service members. Washington, DC: American Council on Education (ACE).

Mensch, K. G, \& Rahschulte, T. (2008). Military leader development and autonomous learning: Responding to the growing complexity of warfare. Human Resource Development Quarterly, 19(3), 263-272.

Merriam, S. B., \& Caffarella, R. S. (1991). Learning in adulthood. San Francisco, CA: Jossey-Bass.

Osland, J. S., \& Bird, A. (2000). Beyond sophisticated stereotyping: Cultural sense making in context. Academy of Management Executive, 14(1), 65-77.

Park, N. (2011). Military children and families: Strengths and challenges during peace and war. American Psychologist, 66(1), 65-72.

Ponton, M. K., \& Carr, P. B. (2000). Understanding and promoting autonomy in self-directed learning. Current Research in Social Psychology 5(19), 271-284.

Ponton, M. K., Derrick, M. G., \& Carr, P. B. (2005). The relationship between resourcefulness and persistence in adult autonomous learning. Adult Education Quarterly, 55(2), 116-128.

Radford, A. W. (2009). Military service members and veterans in higher education: What the new GI Bill may mean for postsecondary institutions. Washington, DC: American Council on Education. Retrieved from http://www.operationpromiseforservicemembers.com/ACE\%20MilService.errata.pdf

Radford, A. W., \& Weko, T. (2011). Military service members and veterans: A profile of those enrolled in undergraduate and graduate education in 2007-08. Washington, DC: U.S. Department of Education, Institute of Education Sciences, National Center for Educational Statistics. Retrieved from http://www.nces.ed.gov/pubs2011/2011163.pdf

Riley, T., \& Ungerleider, C. (2012). Self-fulfilling prophecy: How teachers; attributions, expectations, and stereotypes influence the learning opportunities afforded aboriginal students. Canadian Journal of Education, 35(2), 303-333. 
Shackelford, J. L., \& Maxwell, M. (2012). Sense of community in graduate online education: Contribution of learner to learner interaction. The International Review of Research in Open and Distance Learning, 13(4), 228-249. Retrieved from http://www.irrodl.org/index.php/irrodl/article/view/1339/2346

Soeters, J. L., \& Recht, R. (1998). Culture and discipline in military academies: An international comparison. Journal of Political \& Military Sociology, 26(2), 169-190.

Soeters, J. L., Winslow, D. J., \& Weibull, A. (2006). Military culture. In G. Caforio (Ed.), Handbook of the sociology of the military, (pp. 237-254). New York, NY: Springer.

Starr-Glass, D. (2011a). Military Learners: Experience in the design and management of online learning environments. Journal of Online Learning and Teaching, 7(1), 147-158. Retrieved from http://jolt.merlot.org/vol7no1/starr-glass 0311.pdf

Starr-Glass, D. (2011b). Beginning course surveys: Bridges to knowing and bridges to being. International Review of Research in Open and Distance Learning, 12(5), 135-157. Retrieved from http://www.irrodl.org/index.php/irrodl/article/view/1000/1895

Starr-Glass, D. (2013). Experience of military learners online: Towards mindful practice. Journal of Online Teaching and Learning, 9(3), 353-363. Retrieved from http://jolt.merlot.org/vol9no3/starr-glass_0913.pdf

Starr-Glass, D. (2014a). Moderating the effective co-creation of knowledge in asynchronous online conferences. In C. N. Stevenson and J. C. Bauer (Eds.), Building online communities in higher education institutions: Creating collaborative experience, (pp. 258-278). Hershey, PA: IGIGlobal.

Starr-Glass, D. (2014b). Three degrees of separation: Strategies for mentoring distanced transnational learners. In F. J. García-Peñalvo and A. M. Seoane-Pardo (Eds.), Online tutor 2.0: Methodologies and case studies for successful learning, (pp. 176-200). Hershey, PA: IGI-Global.

Steele, J. L., Salcedo, N., \& Coley, J. (2010). Service members in school: Military veterans' experiences using the Post-9/11 GI Bill and pursuing postsecondary education. Washington, DC: RAND Corporation and American Council on Education. Retrieved from http://www.rand.org/content/dam/rand/pubs/monographs/2011/RAND_MG1083.pdf

Sternberg, M., MacDermid, S., Vaughan, J., \& Carlson, R. (2009). The higher education landscape. West Lafayette, IN: Military Family Research Institute, Purdue University. Retrieved from https://www.mfri.purdue.edu/resources/public/reports/HigherEducationLandscape.pdf

Supplemental Appropriations Act (2008). Public Law No. 110-252, § 4002, 122 Statute 2323 (2008). Retrieved from http://www.gpo.gov/fdsys/pkg/PLAW-110publ252/pdf/PLAW-110publ252.pdf

Swail, W. S., Redd, K. E., \& Perna, L. W. (2003). Retaining minority students in higher education. Stafford, VA: Educational Policy Institute. Retrieved from http://www.educationalpolicy.org/pdf/Retaining\%20Minority\%20Students.pdf

Taylor, B., \& Kroth, M. (2009). Andragogy's transition into the future: Meta-analysis of andragogy and its search for a measureable instrument. MPAEA Journal of Adult Education, 38(1), 1-11. Retrieved from https://www.mpaea.org/docs/pdf/Vol38No12009.pdf

United States Senate. (2012). For profit higher education: The failure to safeguard the federal investment and ensure student success. Washington, DC: United States Senate - Health, Education, Labor, and Pensions Committee. Retrieved from http://www.help.senate.gov/imo/media/for_profit report/PartI-PartIII-SelectedAppendixes.pdf 